\title{
Pengembangan Modul Berbasis Flip and Pop Up Full Games Terintegrasi Keislaman pada Konsep Sistem Pertahanan Tubuh Kelas XI
}

\author{
Maharani Nida Ervina*, Nanik Lestariningsih \\ Program Studi Tadris Biologi, Jurusan Pendidikan MIPA, \\ Fakultas Tarbiyah dan Ilmu Keguruan, Institut Agama Islam Negeri Palangka Raya, Palangka Raya, \\ Kalimantan Tengah, Indonesia \\ Email: raninida09@gmail.com
}

\begin{abstract}
Abstrak
Tujuan penelitian ini adalah untuk mengetahui deskripsi, validitas, dan kepraktisan modul berbasis flip and pop up full games terintegrasi keislaman yang dikembangkan pada konsep sistem pertahan tubuh untuk peserta didik kelas XI MA Darul Ulum Palangka Raya. Penelitian ini mengikuti tahap pengembangan Reseach and Development. Tahap penelitian meliputi potensi masalah, pengumpulan data, desain produk, validasi produk, revisi desain, dan, uji coba produk skala kecil. Penelitian dilakukan pada peserta didik kelas XI MA Darul Ulum Palangka Raya sebagai subjek penelitian. Modul yang dikembangkan memiliki deskripsi berupa modul cetak ukuran $210 \mathrm{~mm} \times 250 \mathrm{~mm}$ yang dicetak pada kertas glossy dengan jilid perfect binding. Modul yang dikembangkan memiliki basis flip and pop up serta memuat konten permainan edukatif berupa teka-teki silang, temu kata, puzzle, dan ular tangga. Adapun isi modul memuat integrasi keislaman dengan konsep yang dibahas serta biosupplement. Hasil penelitian menunjukkan persentase tingkat kevalidan materi modul $94,66 \%$ valid, kevalidan media (desain) modul 85,83\% valid, dan kevalidan integrasi keislaman 86,09\% valid. Adapun kepraktisan modul diperoleh rata-rata persentase sebesar 93,4\% dengan kategori praktis. Berdasarkan hasil penelitian disimpulkan bahwa modul berbasis flip and pop up full games terintegrasi keislaman pada konsep sistem pertahanan tubuh dinyatakan valid dan praktis serta layak digunakan di lapangan.
\end{abstract}

Kata kunci: modul, sistem pertahanan tubuh

\begin{abstract}
The purpose of this study was to determine the description, validity, and practicality of a module based on Islamic integrated flip and pop up full games developed on the concept of immune systems for class XI students of MA Darul Ulum Palangka Raya. This research followed the development stage of Research and Development. The research stage includes potential problems, data collection, product design, product validation, design revision, and small-scale product trials. The research was conducted on students of class XI MA Darul Ulum Palangka Raya as research subjects. The developed module has a description in the form of a $210 \mathrm{~mm} \times 250 \mathrm{~mm}$ print module printed on glossy paper with perfect binding binding. The developed module has a flip and pop up base and contains educational game content in the form of crossword puzzles, word encounters, puzzles, and snakes and ladders. The module content includes the integration of Islam with the concepts discussed and biosupplement. The results showed the percentage level of validity of the module material was $94.66 \%$ valid, the validity of the media (design) module was $85.83 \%$ valid, and the validity of Islamic integration was $86.09 \%$ valid. As for the practicality of the module, an average percentage of $93.4 \%$ was obtained with the practical category. Based on the results of the study, it was concluded that the module based on flip and pop up full games integrated Islam in the concept of the body's defense system was declared valid and practical and suitable for use in the field.
\end{abstract}

Keywords: module, immune system

\section{PENDAHULUAN}

Pendidikan merupakan program penting berupa usaha sadar dan terencana yang merupakan hak untuk didapatkan oleh setiap warga negara. Melalui pendidikan seseorang atau peserta didik akan dapat mengembangkan potensi yang dimiliki, membentuk nilai, sikap, dan perilakunya sesuai tujuan pendidikan melalui pengetahuan yang diperoleh dari kegiatan belajar (Rahmatin, dkk. 2019). 
Demi terlaksana dan tercapainya tujuan pendidikan maka dalam dunia pendidikan diperlukan alat bantu pendidikan. Alat bantu pendidikan yang dimaksud adalah alat atau media yang digunakan oleh pendidik untuk membantu proses pengajaran. Adapun salah satu alat tersebut ialah modul pembelajaran.

Modul adalah bahan ajar berisikan konsep spesifik yang tersusun secara sistematis dan struktural dengan prinsip penggunaan belajar mandiri. Artinya dalam penggunaannya tidak diperlukan penjelasan atau bimbingan dari seorang guru (Lasmiyati, 2014; Nisrokhah, 2016; Dewi dkk, 2017). Melalui modul, pesera didik akan dapat memperoleh informasi terkait konsep pembelajaran lebih mendalam, memperoleh kekayaan wawasan, mengetahui sejauh mana kompetensi yang dimilikinya, serta dapat melakukan evaluasi secara mandiri (Dewi, 2017).

Bahan ajar seperti modul merupakan kebutuhan penting yang dapat memberi pengaruh besar terhadap keberhasilan proses belajar peserta didik, sekalipun peserta didik memiliki bahan ajar lain seperti LKPD, booklet, dan buku paket pelajaran. Beragamnya bahan ajar ataupun sumber belajar akan membuat perserta didik semakin mudah untuk meraih kompetensi atau kapabilitas yang diinginkan serta tujuan pembelajaran sesuai dengan yang diharapkan (Irwandani \& Latifah, 2017; Dewi dkk, 2017; Suhartini, dkk, 2019).

Kenyataannya di MA Darul Ulum bahan ajar yang disediakan masih belum memadai. Perpustakaan di MA Darul ulum tidak menyediakan buku ajar maupun buku pengayaan tentang biologi. Akibatnya untuk mencapai tujuan pembelajaran pada mata pelajaran biologi menjadi sulit diupayakan. Peserta didik hanya menggunakan Lembar Kerja Peserta Didik (LKPD) dalam kegiatan pembelajaran. LKPD yang digunakan hanya memuat uraian materi secara singkat dan belum bisa memvisualisasikan keabstrakan konsep pada beberapa konsep tertentu. Salah satu konsep tersebut adalah sistem pertahanan tubuh yang konsepnya bersifat abstrak. Selain itu kesulitan untuk mencapai tujuan pembelajaran disebakan oleh metode yang digunakan guru ketika mengajar adalah metode konvensional (ceramah). Hal ini terbukti dengan adanya pernyataan guru pengampu mata pelajaran Biologi bahwa, peserta didik masih memperoleh nilai hasil belajar yang berada dibawah Kriteria Ketuntasan Minimal (KKM) pada beberapa konsep dalam mata pelajaran Biologi. Salah satu konsep yang sulit sekali dicapai KKMnya adalah konsep sistem pertahanan tubuh $(\mathrm{KKM}=75)$. Selain itu dari segi sarana dan prasarana, di madrasah masih tidak tersedia laboratorium. Sejatinya, dengan adanya laboratorium peserta didik dapat mengembangkan pengetahuannya serta mengembangkan pemahaman yang telah dimiliki. Di kelas juga masih belum tersedia proyektor sehingga sulit jika ingin mengadakan pembelajaran berbantukan media audio visual yang dapat memberi gambaran lebih detail mengenai suatu konsep yang dibelajarkan.

Pada kesehariannya peserta didik juga tidak diperkenankan membawa barang elektronik seperti telepon genggam ataupun laptop, hal ini membuat akses untuk memperoleh ilmu dari luar tidak dapat 
dijangkau. Selama kegiatan pembelajaran berlangsung peserta didik hanya mendengarkan guru, tak jarang peserta didik merasa bosan bahkan pada beberapa kasus guru menyatakan bahwa ada peserta didik yang asyik mengobrol, tidur, atau melakukan aktivitas lain yang tidak ada kaitannya dengan kegiatan pembelajaran.

Menurut Marti dkk (2014), pada konsep yang bersifat abstrak dan sulit untuk dipahami mestinya tidak cukup bila dalam pembelajarannya hanya disajikan dalam bentuk ceramah ataupun dengan menghafal. Pada kasus ini juga diperlukan adanya bahan ajar atau media yang dapat memvisualisasikan keabstrakan pada konsep tersebut. Sehingga konsep yang dipelajari dapat dengan mudah dipahami.

Oleh karena itu diperlukan bahan ajar berupa modul yang dapat memvisualisasikan keabstrakan konsep dan praktis agar tujuan pembelajaran dapat tercapai dengan mudah. Peran modul dalam mengatasi permasalahan pada kegiatan pembelajaran telah dibuktikan pada beberapa penelitian, salah satunya penelitian dan pengembangan yang telah dilaksanakan oleh Ningrum dkk (2018) yang berjudul "Pengembangan Modul Pop Up Berbasis Inkuiri Terbimbing pada Tema Tata Surya untuk Kelas VII SMP.” Hasil penelitian ini membuktikan bahwa pengembangan modul рор ир berbasis inkuiri terbimbing pada tema tata surya untuk kelas VII SMP 84,4\% efektif meningkatkan hasil belajar ranah peserta didik dan dikategorikan sangat layak.

Berangkat dari masalah yang ada, analisis kebutuhan dan penelitian relevan yang telah diuraikan, maka dirasa perlu adanya penelitian yang berjudul: "Pengembangan Modul Berbasis Flip dan Pop Up Full Games Terintegrasi Keislaman pada Konsep Sistem Pertahanan Tubuh Kelas XI MA.” Pengembangan modul terintegrasi dengan nilainilai Islam diperlukan agar tidak ada lagi pemahaman bahwa biologi (ilmu umum) kurang penting dibanding ilmu agama, atau anggapan bahwa biologi tidak ada hubungannya dengan ilmu agama dapat dihilangkan.

\section{METODE PENELITIAN}

Penelitian dan pengembangan ini dilakukan sejak Maret 2020 sampai dengan Mei 2020. Penelitian ini dilakukan pada 5 orang peserta didik yang dipilih secara acak (random) untuk dilakukan uji skala terbatas penggunaan modul berbasis flip dan pop up full games terintegrasi keislaman pada konsep sistem pertahanan tubuh.

Penelitian ini adalah penelitian dan pengembangan yang menggunakan desain penelitian Sugiyono (2017) yang telah dimodifikisai. Adapun tahap penelitian dan pengembangan yang dilakukan adalah sebagai berikut: 1) Potensi dan Masalah, 2) Analisis Kebutuhan, 3) Pengumpulan Data, 4) Pengembangan Produk, 5) Validasi Desain, 6) Revisi Desain dan 7) Uji Coba Produk.

Berikut ini adalah beberapa jenis instrumen yang digunakan.

a. Instrumen Validasi Ahli Materi

b. Instrumen Validasi Ahli Media

c. Instrumen Validasi Integrasi Keislaman terhadap Konsep oleh Ahli Integrasi 
d. Instrumen Kepraktisan Modul

Instrumen validasi dibuat dalam bentuk angket dengan skala likert. Validator akan mengisi nilai dalam bentuk angka pada skala likert yang disediakan. Selanjutnya data yang diperoleh diolah agar dapat mendeskripsikan validitas bahan ajar yang telah dinilai oleh validator menggunakan rumus berikut.

$$
P=\frac{\sum X_{i}}{\sum X} \times 100 \%
$$

Keterangan:

$\mathrm{P} \quad=$ Persentase

$\sum \mathrm{X}_{\mathrm{i}}=$ Jumlah total skor yang diperoleh dari validator

$\Sigma \mathrm{X}=$ Jumlah skor ideal

Hasil perhitungan yang diperoleh diterjemahkan maknanya dengan kualifikasi sebagai berikut.

Tabel 1. Kategorisasi Tingkat Kevalidan

Modul

\begin{tabular}{cc}
\hline Persentase (\%) & Tingkat Kevalidan \\
\hline $80 \leq \mathrm{P} \leq 100$ & Valid/tidak revisi \\
$60 \leq \mathrm{P} \geq 79$ & Cukup valid/tidak revisi \\
$40 \leq \mathrm{P} \geq 59$ & Kurang valid/revisi \\
& sebagian \\
$0<\mathrm{P} \geq 39$ & Tidak valid/revisi
\end{tabular}

(Arikunto, 2009)

1. Revisi Desain

Produk yang telah dikembangkan akan dilakukan revisi desain apabila setelah validasi masih diperlukan adanya perbaikan. Revisi desain meliputi perbaikan isi maupun konten dalam modul yang dikembangkan.
2. Uji Coba Produk

Produk yang telah divalidasi diuji cobakan pada skala terbatas pada peserta didik yang bukan bagian dari sampel penelitian. Uji coba produk skala terbatas ini dilakukan kepada 5 orang peserta didik kelas XII untuk mengetahui kepraktisan modul yang dikembangkan. Data yang diperoleh diolah untuk menentukan kategorisasi validitas kepraktisan bahan ajar yang dikembangkan. Berikut adalah rumus yang digunakan.

$$
P=\frac{\sum X_{i}}{\sum X} \times 100 \%
$$

Keterangan:

$\mathrm{P} \quad=$ Persentase

$\sum \mathrm{X}_{\mathrm{i}}=$ Jumlah total skor yang diperoleh

$\sum \mathrm{X}=$ Jumlah skor ideal

Hasil perhitungan yang diperoleh diterjemahkan maknanya dengan kualifikasi sebagai berikut.

Tabel 2. Kategorisasi Tingkat Kepraktisan Modul

\begin{tabular}{cc}
\hline Persentase (\%) & Tingkat Kevalidan \\
\hline $80 \leq \mathrm{P} \leq 100$ & Praktis \\
$60 \leq \mathrm{P} \geq 79$ & Cukup praktis \\
$40 \leq \mathrm{P} \geq 59$ & Kurang praktis \\
$0<\mathrm{P} \geq 39$ & Tidak praktis \\
\hline
\end{tabular}

(Arikunto, 2009)

\section{HASIL PENELITIAN}

Berikut ini adalah uraian hasil penelitian berdasarkan tahapan desain yang di lakukan.

\section{Validasi Produk}


Pada penelitian dan pengembangan ini validasi modul dilakukan terhadap tiga aspek sebagai berikut.

a. Validasi Materi

Validasi materi modul dilakukan oleh 2 orang validator ahli materi. Validasi materi dilakukan oleh ahli materi dengan menggunakan instrumen validasi sesuai standar BSNP (2014) tentang standar instrumen validasi materi bahan ajar yang juga telah divalidasi oleh validator. Hasil validasi materi modul yang dikembangkan oleh 2 orang validator materi meperoleh rata-rata persentase kevalidan $94,66 \%$ dengan kategori valid dan simpulan layak digunakan di lapangan tanpa revisi. Berikut ini adalah hasil validasi materi modul berbasis flip dan pop up full games pada konsep sistem pertahanan tubuh.

Tabel 3. Hasil Validasi Materi Modul oleh Validator 1

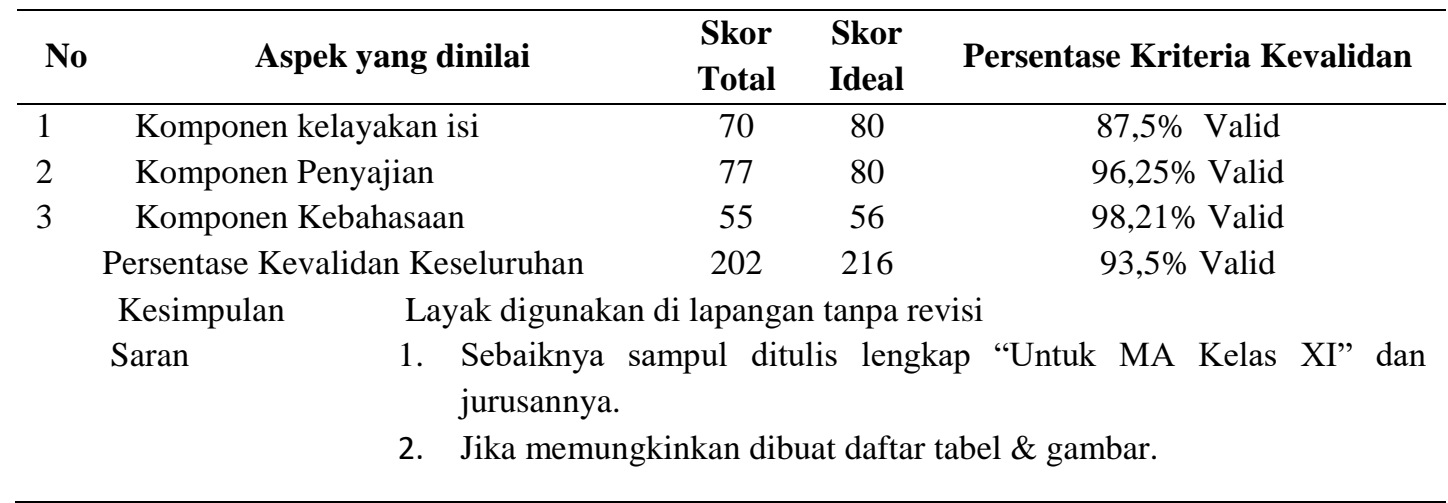

Tabel 4. Hasil Validasi Materi Modul oleh Validator 2

\begin{tabular}{|c|c|c|c|c|}
\hline No & Aspek yang dinilai & $\begin{array}{l}\text { Skor } \\
\text { Total }\end{array}$ & $\begin{array}{l}\text { Skor } \\
\text { Ideal }\end{array}$ & Persentase Kriteria Kevalidan \\
\hline 1 & Komponen kelayakan isi & 75 & 80 & $93,75 \%$ Valid \\
\hline 2 & Komponen Penyajian & 77 & 80 & $96,25 \%$ Valid \\
\hline \multirow[t]{3}{*}{3} & Komponen Kebahasaan & 55 & 56 & $96,21 \%$ Valid \\
\hline & Persentase Kevalidan Keseluruhan & 207 & 216 & $95,83 \%$ Valid \\
\hline & Kesimpulan Layak digunal & lapang & tanpa 1 & visi \\
\hline \multirow[t]{4}{*}{ Sara } & & \multicolumn{3}{|c|}{$\begin{array}{l}\text { 1. Gunakan karakter atau ilustrasi lokal yang dapat menunjukkan } \\
\text { identitas, kekayaan, atau budaya Indonesia. }\end{array}$} \\
\hline & \multicolumn{4}{|c|}{ 2. Gunakan font yang berbeda pada biosupplement. } \\
\hline & \multicolumn{4}{|c|}{$\begin{array}{l}\text { 3. Masukkan intruksi untuk tidak melihat kunci jawaban pada petunjuk } \\
\text { penggunaan modul. }\end{array}$} \\
\hline & \multicolumn{4}{|c|}{ 4. Gunakan ajakan yang bersifat tidak memerintah. } \\
\hline
\end{tabular}

Berdasarkan perolehan nilai dari 2 validator materi dapat dilihat perbandingannya pada grafik berikut. 


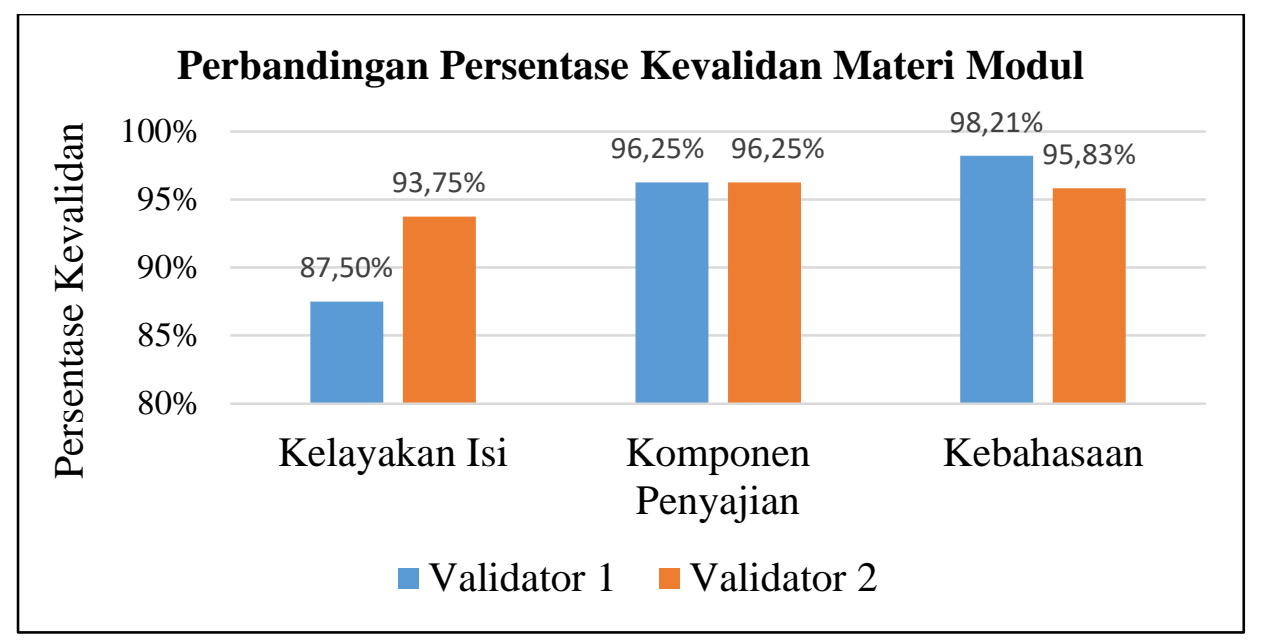

Gambar 1. Grafik Persentase Kevalidan Materi Modul

Berdasarkan penilaian dari 2 validator terhadap validasi materi modul pada tiap aspek diperoleh rata-rata kevalidan sebagai berikut.

1) Rata-rata kevalidan kelayakan isi modul $90,6 \%$

2) Rata-rata kevalidan komponen penyajian isi modul $96,25 \%$

3) Rata-rata kevalidan kebahasaan $97,21 \%$

\section{b. Validasi Media (Desain)}

Validasi media (desain) modul dalam penelitian dan pengembangan ini menggunakan instrumen validasi desain bahan ajar sesuai standar instrumen validasi desain oleh BSNP (2014). Adapun 2 orang validator ahli desain tersebut adalah:

1) Ibu Usmyatun, M. Pd. (dosen (mengajar IT)) sebagai validator 1.

2) Bapak Bayu Angga Kurniawan, S. Kom (praktisi designer of Manilla Redsquare, praktisi desain grafis dan Vector Illustrator) sebagai validator 2 .

Hasil validasi media (desain) modul yang dikembangkan oleh 2 orang validator ahli media/desain meperoleh rata-rata persentase kevalidan 85,83 \% dengan kategori valid dan simpulan layak digunakan di lapangan tanpa revisi. Berikut ini adalah data hasil validasi desain modul berbasis flip dan pop up full games pada konsep sistem pertahanan tubuh dari masing-masing validator.

Tabel 5. Hasil Validasi Media (Desain) Modul oleh Validator 1

\begin{tabular}{llccc}
\hline No & Aspek yang dinilai & $\begin{array}{c}\text { Skor } \\
\text { Total }\end{array}$ & $\begin{array}{c}\text { Skor } \\
\text { Ideal }\end{array}$ & Persentase Kriteria Kevalidan \\
\hline 1 & Ukuran modul & 8 & 8 & $100 \%$ Valid \\
2 & Desain cover modul & 39 & 40 & $97,5 \%$ Valid \\
3 & Desain isi modul & 66 & 72 & $91,6 \%$ Valid \\
& Persentase Kevalidan Keseluruhan & 113 & 120 & $94,16 \%$ Valid \\
\hline
\end{tabular}




\begin{tabular}{ll}
\hline Kesimpulan & Layak digunakan di lapangan tanpa revisi \\
Komentar & Desain modul yang dikembangkan sudah bagus \\
\hline
\end{tabular}

Tabel 6. Hasil Validasi Media (Desain) Modul oleh Validator 2

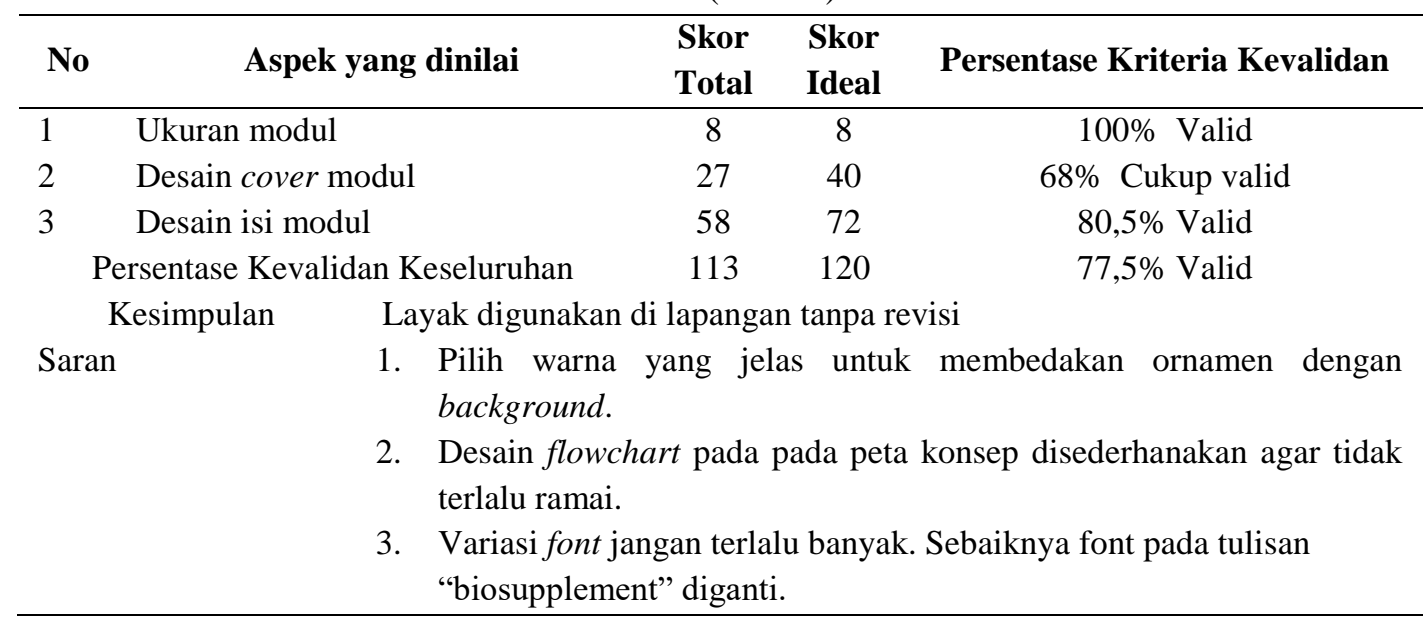

Berdasarkan penilaian dari 2 validator media (desain) diperoleh penilaian berbeda Berikut ini adalah grafik perbandingan nilai dari 2 orang validator media (desain).

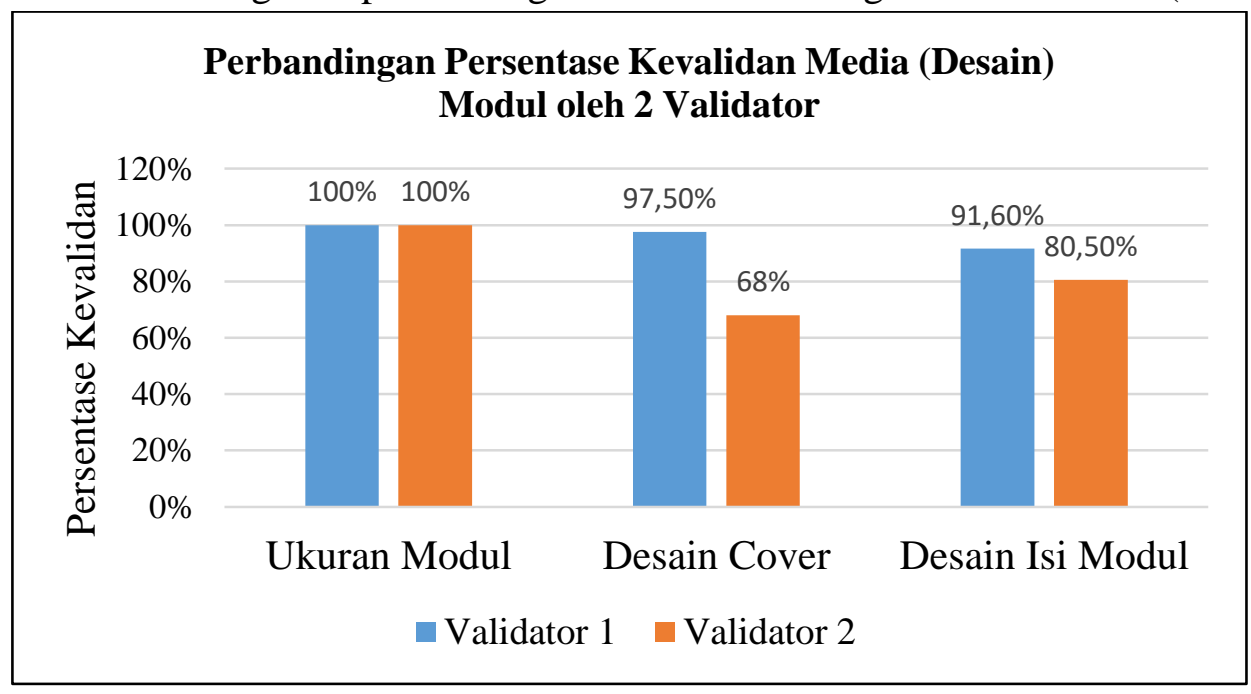

Gambar 2. Grafik Perbandingan Persentase Kevalidan Desain Modul

Berdasarkan penilaian dari 2 orang validator media (desain) tiap aspek desain diperoleh rata-rata kevalidan sebagai berikut.

1) Rata-rata kevalidan ukuran modul $100 \%$

2) Rata-rata kevalidan desain cover atau sampul modul $82,75 \%$

3) Rata-rata kevalidan desain isi modul $86,05 \%$

c. Validasi Integrasi Keislaman

\section{terhadap Konsep}

Validasi integrasi keislaman

pada penelitian dan pengembangan

ini dilakukan oleh satu orang validator yaitu, Bapak Hendra Fitra Candra, M. Pd. yang berprofesi sebagai akedemisi (dosen) pada mata kuliah tafsir, tasawuf, metodologi 
studi islam, dan mata kuliah lain yang

berbasis keagamaan.

Hasil validasi integrasi

keislaman pada modul yang

dikembangkan secara keseluruhan

adalah 86,09\% valid. Adapun modul pada aspek integrasi islam dengan sains adalah $85 \%$ valid, aspek integrasi nilai keislaman 91,66\% dengan kategori valid, dan kevalidan aspek kebahasaan 91,66\% dengan kategori valid.

kevalidan integrasi keislaman pada

Tabel 7. Hasil Validasi Integrasi Keislaman Modul

\begin{tabular}{|c|c|c|c|c|}
\hline No & Aspek yang Dinilai & $\begin{array}{l}\text { Skor } \\
\text { Total }\end{array}$ & $\begin{array}{l}\text { Skor } \\
\text { Ideal }\end{array}$ & Persentase Kriteria Kevalidan \\
\hline 1 & Integrasi Islam dengan Sains & 17 & 20 & $85 \%$ Valid \\
\hline 2 & Integrasi Nilai Keislaman & 11 & 12 & $91,66 \%$ Valid \\
\hline 3 & Kebahasaan & 11 & 12 & $91,66 \%$ Valid \\
\hline \multicolumn{2}{|r|}{ Persentase Kevalidan Keseluruhan } & 37 & 44 & $88,63 \%$ Valid \\
\hline $\begin{array}{l}\text { Kesimpulan } \\
\text { Saran }\end{array}$ & $\begin{array}{ll}\text { mpulan } & \text { Layak digunakan di } \\
& \text { 1. Tambahkan soa } \\
\text { 2. Tambahkan aya }\end{array}$ & \multicolumn{3}{|c|}{$\begin{array}{l}\text { 1. Tambahkan soal terkait integrasi keislaman } \\
\text { 2. Tambahkan ayat al-Qur'an lebih banyak terkait konsep }\end{array}$} \\
\hline
\end{tabular}

Berikut ini adalah grafik tingkat kevalidan integrasi keislaman peraspeknya pada modul yang dikembangkan.

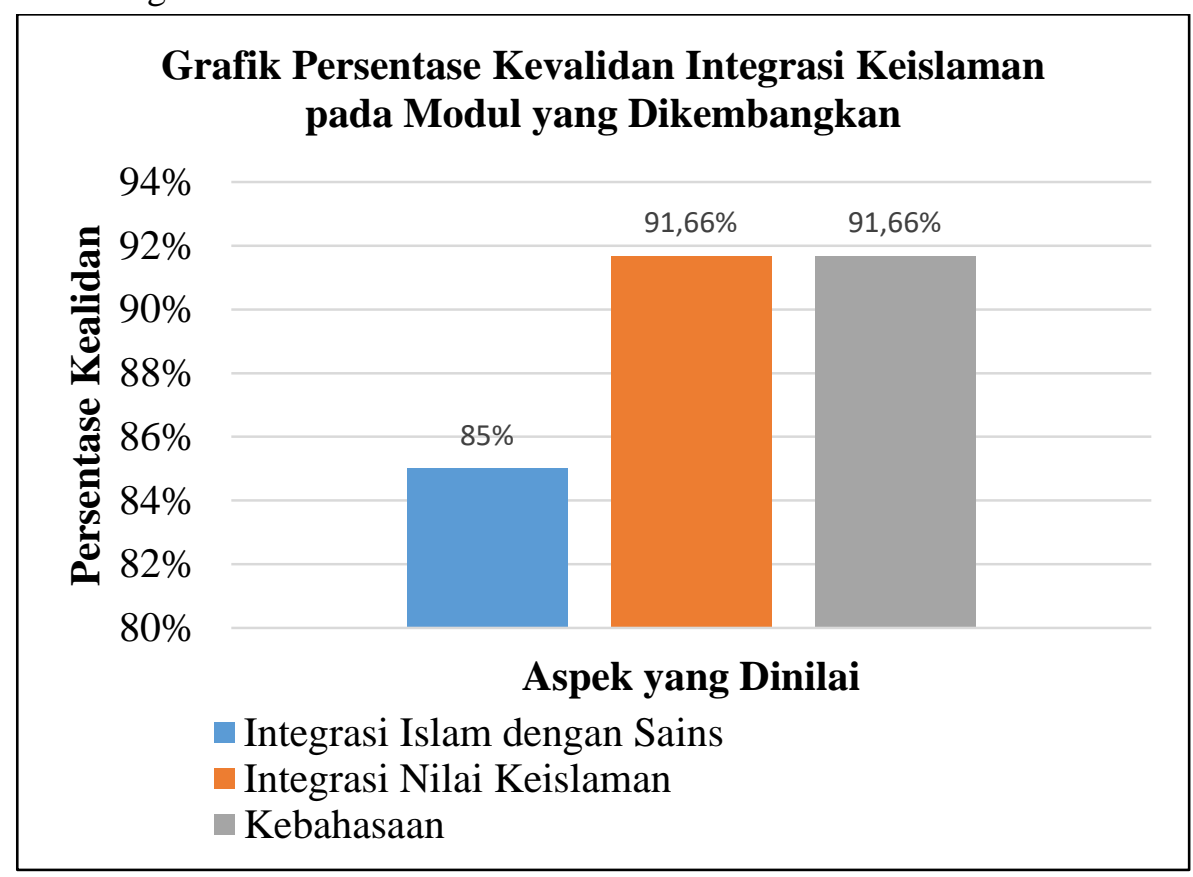

Gambar 3. Grafik Rata-rata Persentase Kevalidan Integrasi Keislaman Modul

\section{Revisi Produk}

Modul yang dikembangkan telah divalidasi oleh lima validator. Kelima validator memberikan kesimpulan yang berbeda. Berdasarkan hasil validasi terdapat saran-saran yang diberikan oleh validator, baik validator materi, validator media (desain), maupun validator integrasi keislaman. Beberapa validator, yaitu validator 1 ahli materi dan validator 1 ahli 
media menyimpulkan bahwa produk telah layak dan dapat digunakan di lapangan tanpa revisi, sedangkan validator 2 ahli materi, validator 2 ahli desain media dan validator integrasi keislaman menyatakan layak digunakan di lapangan dengan revisi. Revisi dilakukan pada desain cover modul sesuai saran dari validator ahli materi 1. Selain itu revisi desain dilakukan pada bagian isi modul sesuai saran dari validator 2 ahli materi, validator 2 ahli desain media dan validator integrasi keislaman. Adapun revisi yang dilakukan meliputi penggantian font huruf pada biosupplement, penggantian ilustrasi dengan ilustrasi yang menunjukkan identitas indonesia, dan penambahan soal yang berkaitan dengan hadits yang diintegrasikan dan penambahan ayat alQur'an yang berintegrasi dengan konsep sistem pertahanan tubuh. Berikut adalah revisi yang telah dilakukan.

Tabel 8. Kepraktisan Penggunaan Modul

\begin{tabular}{|c|c|c|c|c|}
\hline \multirow[b]{2}{*}{ Responden } & \multicolumn{2}{|c|}{ Aspek Kepraktisan yang Dinilai } & \multirow[b]{2}{*}{$\begin{array}{c}\text { Skor } \\
\text { Kepraktisan } \\
\text { Tiap } \\
\text { Responden } \\
\text { (S. Ideal 100) }\end{array}$} & \multirow[b]{2}{*}{$\begin{array}{c}\text { Persentase \& Kategori } \\
\text { Kepraktisan Tiap } \\
\text { Responden }\end{array}$} \\
\hline & $\begin{array}{l}\text { Kemudahan } \\
\text { Penggunaan } \\
\text { (Skor Ideal 32) }\end{array}$ & $\begin{array}{c}\text { Kemudahan } \\
\text { Memahami } \\
\text { (Skor Ideal 68) }\end{array}$ & & \\
\hline PD 1 & 30 & 61 & 91 & $91 \%$ Praktis \\
\hline PD 2 & 29 & 65 & 94 & $94 \%$ Praktis \\
\hline PD 3 & 31 & 67 & 98 & $98 \%$ Praktis \\
\hline PD 4 & 29 & 62 & 91 & $91 \%$ Praktis \\
\hline PD 5 & 30 & 63 & 93 & $93 \%$ Praktis \\
\hline Rata-rata & 29,8 & 63,8 & 93,4 & \\
\hline Persentase & $90,31 \%$ & $93,82 \%$ & $93,4 \%$ & 93,4\% Praktis \\
\hline Kriteria & Praktis & Praktis & Praktis & \\
\hline
\end{tabular}

\section{PEMBAHASAN}

\section{Validitas Modul}

Validitas modul yang

dikembangkan dalam penelitian ini telah dilakukan terhadap tiga aspek, yaitu validitas materi, validitas media (desain), dan validitas integrasi keislaman. Validitas modul dilakukan mengingat pentingnya tahap ini dalam sebuah penelitian dan pengembangan (research and development). Sugiyono (2017) mengatakan bahwa setiap produk yang dihasilkan dari penelitian dan pengembangan (research and devlopment) perlu divalidasi oleh validator yang merupakan ahli dibidangnya sebelum produk tersebut diuji cobakan dan diproduksi secara masal. Hal ini bertujuan untuk menjamin bahwa produk yang diciptakan benarbenar dapat dipercaya, digunakan, dan telah memenuhi standar.

a. Validitas Materi Modul

Modul yang dikembangkan telah divalidasi oleh 2 orang validator materi yang merupakan ahli materi sesuai bidangnya. Modul 
yang dikembangkan dibuat dengan memenuhi standar validitas materi modul menurut BSNP (2014). Berikutnya, modul yang dikembangkan juga telah memenuhi aspek kelayakan isi, komponen penyajian, dan kebahasaan yang sesuai dengan standar BSNP (2014). Berdasarkan hasil validasi diperoleh rata-rata persentase kevalidan materi modul secara keseluruhan adalah 94,66\% dengan kategorisasi valid. Adapun rata-rata kevalidan materi modul peraspeknya yaitu, komponen kelayakan isi 90,6\% valid, komponen penyajian 96,25\% valid, dan kebahasaan 97,21\% valid. Data ini diperoleh dari hasil perhitungan rata-rata kevalidan modul dari 2 orang validator.

Selain itu modul yang dibuat juga telah disesuaikan dengan ketentuan bahan ajar untuk SMA atau MA dengan tahap penyusunan yang sistematis, menunjang ketercapaian kompetensi inti dan kompetensi dasar, relevan dengan perkembangan jaman, dan dapat menciptakan suasana yang memungkinkan peserta didik untuk belajar. Hal ini sesuai dengan bahan ajar menurut DEPDIKNAS (2006) bahwa, bahan ajar merupakan seperangkat materi yang disusun secara sistematis, baik tertulis maupun tidak sehingga tercipta lingkungan atau suasana yang memungkinkan siswa (peserta didik) untuk belajar.

Materi yang dikembangkan pada modul diformulasikan dengan memperhatikan dan menyesuaikan sasaran yang dituju. Sehingga materi yang disajikan sesuai dengan tingkat berpikir peserta didik dan sesuai dengan perkembangan sosial dan emosionalnya. Menurut Prastowo (2015), dalam memformulasikan materi penting sekali untuk memperhatikan target pembaca yang dituju, sehingga dapat diketahui batasan pengembangan materi. Prastowo (2015) juga menyatakan bahwa materi yang di-kembangkan di dalam modul hendaknya memberikan perhatian yang sama ketika meng-akomodasikan tingkat kemampuan pembaca yang ditargetkan agar materi yang dikembangkan menjadi mudah dimengerti.

Berdasarkan rata-rata persentase kebahasaan diperoleh hasil 97,21\% dengan kategori valid. Kebahasaan dalam penyampaian materi modul selain mengikuti standar BSNP tahun 2014 juga memperhatikan gaya penulisan yang disesuaikan dengan sasaran pengguna modul. Sehingga pesan di dalam modul mudah tersampaikan kepada peserta didik. Adapun gaya penulisan yang diperhatikan 
berdasarkan aspek kebahasaan pada modul yang dikembangkan mengikuti gaya penulisan yang diterangkan oleh Rowntree (1994) yaitu: 1) menggunakan kata-kata yang seolah mengajak berbicara pembaca, 2) menggunakan kata ganti orang pertama, 3) memberi kesan bicara secara langsung, 4) menulis mengenai orang, benda, dan fakta, 5) menggunakan kalimat aktif dan subjek personal, 6) menggunakan kata kerja, 7) menggunakan paragraf dan kalimat yang singkat serta retorika, 8) melakukan dramatisasi jika diperlukan, 9) menggunakan ilustrasi, contoh, atau kasus (Prastowo, 2015). Kaidah gaya penulisan seperti yang diterangkan di atas sangat cocok diterapkan kepada peserta didik sebab mampu menyampaikan pesan dengan lebih efektif (Prastowo, 2015).

b. Validitas Media (Desain)

Modul yang dikembangkan telah divalidasi oleh 2 orang validator media (desain) dan diperoleh persentase rata-rata kevalidan secara keseluruan sebesar 85,83\% dengan kategorisasi valid. Berdasarkan aspek validitas media atau desain menurut standar BSNP (2014) terdapat 3 aspek yang dinilai, yaitu ukuran modul, desain cover atau sampul modul, dan desain isi modul. Berdasarkan hasil validasi diperoleh persentase rata-rata kevalidan aspek desain pada ukuran modul $100 \%$ valid, desain cover atau sampul modul $82,75 \%$ valid, dan desain isi modul $86,05 \%$ valid.

Data persentase kevalidan yang diperoleh merupakan hasil perhitungan rata-rata validasi oleh 2 validator media (desain). Berdasaran hasil validasi media (desain) diperoleh kesimpulan bahwa modul yang dikembangkan layak digunakan di lapangan tanpa revisi oleh masing-masing validator media (desain). Format desain modul telah disusun dengan memperhatikan frekuensi dan konsistensi untuk menghindari kontraproduktif. Selain itu desain modul yang dikembangkan disusun secara sistematis sehingga mudah dibaca dan dimengerti oleh peserta didik. Modul yang dikembangkan juga didesain dengan variasi format dan ilustrasi agar lebih menarik. Sehingga dari sisi desain, modul yang dikembangkan telah memiliki desain yang baik dan dinyatakan valid oleh validator media (desain).

Menurut Prastowo (2015) untuk memperoleh desain modul yang baik sangat perlu memperhatikan format desain. Adapun format desain yang dimaksud diantaranya gaya penulisan, tata letak, dan karakteristik desain yang 
disesuaikan dengan kebutuhan pembaca. Prastowo (2015) juga menyatakan bahwa desain modul yang baik adalah desain yang membuat peserta didik dapat lebih mudah dalam memahami isi modul. Contohnya dengan mengadakan variasi tampilan fisik dengan ilustrasi, jenis font yang menarik namun terbaca, dan susunan modul yang sistematis dengan tetap memperhatikan konsistensi (Prastowo, 2015).

c. Validitas Integrasi Keislaman Modul yang dikembangkan memuat konsep yang diintegrasikan dengan keislaman. Sehingga di dalamnnya terdapat integrasi ayat al-Qur'an dan hadits terhadap konsep yang dibahas serta integrasinya dengan nilai-nilai keislaman yang lain. Hasil validasi integrasi keislaman pada modul yang dikembangkan secara keseluruhan adalah $88,63 \%$ valid. Adapun kevalidan integrasi keislaman pada modul pada aspek integrasi islam dengan sains adalah $85 \%$ valid, aspek integrasi nilai keislaman 91,66\% dengan kategori valid, dan kevalidan aspek kebahasaan 91,66\% dengan kategori valid.

Integrasi keislaman pada modul yang dikembangkan bukan hanya sebagai novelty dari penelitian dan pengembangan, melainkan sebab adanya urgensi untuk membangun pondasi kesadaran ketuhanan yang mengiringi proses menuntut ilmu. Adanya pondasi kesadaran ketuhanan akan membuat peserta didik yang sedang belajar tidak hanya akan menjadi individu yang berilmu, melainkan juga bermoral dan beradab (Wathoni, 2018). Selain itu adanya integrasi keislaman dalam pembelajaran memudahkan peserta didik untuk meraih kompetensi sikap spiritualnya.

Wathoni (2018) menyatakan bahwa al-Qur'an itu sejatinya selalu relevan dengan ilmu pengetahuan (sains) yang saat ini terus berkembang dengan sangat pesat. Baik ilmu agama maupun ilmu pengetahuan (sains) keduanya saling berikatan dan berintegrasi. Setidaknya ada lebih dari 750 ayat al-Qur'an yang berbicara tentang sains dan teknologi. Itu artinya secara tersirat dalam tersurat umat muslim memiliki kewajiban untuk menuntut ilmu agama dan ilmu pengetahuan (duniawi) seperti sains sehingga keduanya menjadi satukesatuan yang koheren (Wathoni, 2018).

\section{Kepraktisan Modul}

Modul yang dikembangkan telah diteliti kepraktisannya dalam uji coba produk skala kecil. Penelitian mengenai kepraktisan modul melalui uji coba 
produk skala kecil mempeoleh rata-rata persentase kepraktisan 93,4\% dengan kategori praktis. Artinya modul yang dikembangkan mudah digunakan dalam kegiatan belajar, tidak merepotkan, efisien, dan mudah dipahami. Menurut Rizki \& Nego (2017), bahan ajar yang baik adalah bahan ajar yang tidak hanya valid, melainkan juga praktis untuk digunakan dan praktis dalam memahaminya.

Kepraktisan (kemudahan) penggunaan modul berdasarkan aspek kepraktisan diperoleh rata-rata persentase 90,31\% dengan kategori praktis. Data perolehan rata-rata persentase kepraktisan penggunaan modul lebih dari $80 \%$ artinya modul dinyatakan praktis. Menurut Alfiriani dan Ellbert (2017)

\section{SIMPULAN}

a. Deskripsi modul yang dikembangkan berupa flip dan pop up, materi yang termuat di dalamnya terintegrasi dengan keislaman, lembar kegiatan peserta didik dan penugasan disusun dalam bentuk permainan edukatif, dan terdapat konten biosupplement yang berisi informasi pendukung pada konsep yang dibahas di dalam modul.

b. Hasil validasi modul menunjukkan bahwa tingkat kevalidan materi modul adalah 94,66\% dengan kategori valid, tingkat kevalidan media (desain) modul 85,83\% dengan kategori valid, dan tingkat modul yang dikembangkan dinyatakan praktis jika mudah digunakan. Mudah dalam penggunaan yang dimaksud adalah mudah digunakan oleh peserta didik untuk belajar, sehingga pembelajaran yang dilakukan secara mandiri menjadi mudah terlaksana, menarik, menyenangkan, dan dapat meningkatkan kreativitas (Alfiriani dan Ellbert, 2017). Adapun kepraktisan (kemudahan) dalam memahami modul diperoleh rata-rata persentase 93,82\% dengan kategori praktis. Artinya modul yang dikembangkan praktis untuk dipahami isinya oleh peserta didik. Modul yang baik dan praktis adalah modul yang materinya telah diformulasikan dengan tepat sehingga mudah dimengerti (Prastowo, 2015).

kevalidan integrasi keislaman 88,63\% dengan kategori valid.

c. Modul diuji kepraktisannya dan memperoleh rata-rata persentase kepraktisan sebesar 93,4\% dengan kategorisasi praktis, artinya modul yang dikembangkan mudah digunakan dan dipahami oleh peserta didik.

\section{DAFTAR PUSTAKA}

Alfiriani A, Hutabri E. 2017. Kepraktisan dan Keefektifan Modul Pembelajaran Bilingual Berbasis Komputer. Jurnal Kependidikan 1 (1). 
Aribowo. 2017. Media Pembelajaran DIY: Membuat Flash Card dan Teka Teki Silang Mandiri. INA-Rxiv.

Arikunto S. 2009. Dasar-Dasar Evaluasi Pendidikan. Jakarta: Bumi Aksara.

Dewi EP. 2017. Efektivitas Modul dengan Model Inkuiri untuk Menumbuhkan Keterampilan Proses Sains Siswa pada Materi Kalor. Tadris: Jurnal Keguruan dan Ilmu Tarbiyah 2(2).

Fatimah DDS, Dewi T \& Cecep SM. 2017. Perancangan Game Puzzle untuk Pembelajaran Menggunakan Metodologi Multimedia. Jurnal Algoritma Sekolah Tinggi Teknologi Garut 14 (2).

Irwandani LS, Asyhary A, Muzannur \& Widyanti. 2017. Modul Digital Interaktif Berbasis Articulate Studio'13: Pengembangan pada Materi Gerak Melingkar Kelas X. Jurnal Ilmiah Pendidikan Fisika Al-Biruni, (6)2.

Lasmiyati, Harta I. 2014. Pengembangan Modul Pembelajaran untuk Meningkatkan Pemahaman Konsep dan Minat SMP. Phytagoras: Jurnal Pendidikan Matematika 9(2).

Mc Cawley, Paul. 2004. Methods for Conducting an Educational Needs Assessment. Moscow: Univercity of Idaho.

Marti S, Panjaitan GP. 2014. Efektivitas Pembelajaran Kooperatif Tipe NHT (Numbered Heads Together) Dengan Media Visual Terhadap Hasil Belajar Peserta didik Padamateri Organisasi Kehidupan Di Kelas Vii Smp Rehoboth.
Jurnal Pendidikan Matematika dan IPA $5(2)$.

Mawarni P, Mawardi, Yahya M. 2020. Penggunaan Media Permainan Ular Tangga Terhadap Motivasi Belajar Sejarah Siswa Kelas XI IPS 1 MAN 2 Banda Aceh. Banda Aceh. Jurnal Ilmiah Mahasiswa (JIM): Jurnal Ilmiah Mahasiswa Pendidikan Sejarah, 5(1).

Nisrokhah. 2016. Pengembangan Modul Mata Kuliah Sejarah Pendidikan Islam di Sekolah Tinggi Ilmu Tarbiyah Pemalang. Jurnal Teknologi Pendidikan, (18)1.

Prastowo A. 2015. Panduan Kreatif Membuat Bahan Ajar Inovatif. Yogyakarta: Diva Press.

Rahmatin N. 2019. Pengembangan Modul Pembelajaran Bangun Ruang Dengan Metode CPS pada Siswa Kelas VIII SMP. JTAM, 3(1).

Suhartini N, Meini SS, Nurmida CS. 2019. Pengembangan Modul Pembelajaran IPS Berorientasi Student Center Learning dalam Blended Learning Kelas VII SMP NEGERI 4 Surabaya. Jurnal Education and Development, 7(3).

Sugiono. 2017. Metode Penelitian Kuantitatif, Kualitatif, dan $R \& D$. Cetakan Ke-26. Bandung: ALFABETA cv.

Tjiptiany EN, As'ari AR, Muksar M. 2016. Pengembangan Modul Pembelajaran Matematika dengan Pendekatan Inkuiri untuk Membantu Siswa SMA Kelas X dalam Memahami Materi Peluang. Jurnal Pendidikan: Teori, Penelitian, dan Pengembangan, 1 (10). 
Wathoni, Nurul LM. 2018. Integrasi

Pendidikan Islam dalam Sains:

Rekonstruksi Paradigma Pendidikan
Islam. Ponorogo: CV Uwais Inspirasi Indonesia. 